B.H. Yerznkyan

\title{
THE IMPORTANCE OF CULTURAL AND INSTITUTIONAL CONTEXTS FOR MANAGING LARGE-SCALE ECOSYSTEMS OF VARIOUS LEVELS
}

\begin{abstract}
The importance of cultural and institutional contexts for a correct understanding of the state and prospects of development of large-scale ecosystems of a different level - national, regional, sectoral, corporate, etc. is analyzed. Consideration of these contexts is necessary for adequate management of specific ecosystems.

Keywords: cultural context, institutional context, large-scale ecosystems, management.

JEL Classification: A12, B40, D21, M12, M14, O15, P00, Z10.
\end{abstract}

\section{INTRODUCTION}

Efficiency of managing the development of large-scale systems depends largely on the cultural and institutional context specificity. Culture and institutions, regarded from economic perspective, are related concepts - especially culture and informal institutional constraints such as "codes of conduct, norms of behavior, and conventions", which are "a part of heritage that we call culture" [1, pp. 36, 37]. The impact of culture and institutions on economic behavior regarded from the different positions, including quantified and qualified ones, is studied inter alia in [2].

National and cultural differences of socioeconomic reforms are considered, as well as relations between culture and economic systems, culture and institutions, influence of culture on inter-firm relations on the example of Russian corporations which use hybrid agreements and mechanisms of transaction management

\section{Cultural And Institutional Contexts}

Cultural context is one of the major factors explaining the notion of the widely divergent paths of historical change. Culture can be defined, after Geert Hofstede, as the collective programming of the mind that distinguishes the members of one group or category of people from others. Being a collective phenomenon, culture can be connected to a verity of collectives, such as tribes or ethnic groups, nations, organizations, occupations, genders, generations, social classes and so on. For example, societal cultures reside (often unconsciously) in values, in the sense of broad tendencies to prefer certain states of affairs over others, while organizational cultures reside rather (visibly and consciously) in practices: the way people perceive what goes on within their organizational environment [3, p. 3].

Culture is one of the major factors explaining the notion of the widely divergent paths of historical change. "This divergence", claims Douglass North, "is even perplexing in terms of standard neoclassical and international trade theory, which implies that over time economies, as they traded goods, services, and productive factors, would gradually con- 
verge". But the puzzle is that we, in the whole, observe the divergence, not the convergence. Why is that? Because "an overwhelming feature of the last ten millennia is that we have evolved into radically different religious, ethnic, cultural, political, and economic societies and the gap between rich and poor nations, between developed and underdeveloped nations, is wide today as ever was and perhaps a great deal wider than ever before" [1, p. 6].

Institutional context is connected to activity of all institutions - both formal and informal. Culture and institutions may be well enough understood in the language of information transmission "from one generation to the next, via teaching and imitation, of knowledge, values, and other factors that influence behavior" [4, p. 2]. The ability of culture and institutions to mutually reinforce is a good basis for their synthesis, i.e. synthesis of the cultural and institutional contexts.

Douglas North the idea of the importance of these two contexts expresses in such way: "Even the Russian Revolution, perhaps, the most complete formal transformation of a society we know, cannot be completely understood without exploring the survival and persistence of many informal constrains" which come, let us remind, "from socially transmitted information" as "a part of the heritage that we call culture" [1, p. 37].

The characteristics of culture and institutions especially matter in comparing the two social orders - one with open access and the other with limited access to political and economic power. It is of great importance that the currently dominant in the West open access orders (OAO) are the result of a specific historical, cultural and political-economic evolution of the Anglo-Saxon world and the related area of continental Europe. Special attention, along with the cultural and religious and other institutional factors, should be given to the linguistic shifts as the indicators of more than a thousand years of evolution from limited to open access orders, focused in the transformation of the synthetic structure of the language into the analytic type, characteristic of modern English and (to a lesser extent) of other German (and Romanic) languages. The imposition of OAO as a model for borrowing by natural states, such as Russia, where the limited access orders (LAO) dominate and, in respect of the language (except, in particular, China with its consistently analytic language) - another, i.e. synthetic culture, tradition, institutional structure prevails, is devoid of evidence-based epistemological and ontological framework. The result of uncritical borrowing can be, instead of the development of the economy, the loss of own, albeit inefficient, identity due to the conflict between the analytics of institutions and the synthetics of their carriers, and the ensuing degradation and transformation into an appendage (raw material appendage - in case of Russia) of the Western world. To avoid this, the policy option should be construction (without reference to the logic of OAO) of institutions facilitating the evolution / transformation of the natural states and their economic development, rather than artificial copying of the institutional forms of OAO [5]. 


\section{LARGE-SCALE SYSTEMS OF VARIOUS LEVELS}

On the national level, for an adequate description of specificity and features of human nature, and, therefore, the behavior of economic agents, it is necessary to take into account, as for Francis Fukuyama, genetic (in the form of propensities or predispositions) and cultural factors (fixed by means of the learning mechanism) factors [6].

National specificity is superimposed on genetics: on the whole, Western civilizations with their inherent two-valued logic of thinking and the dominance of open access orders in society are more prone to economic exchanges - transactions, while Eastern civilizations, with their multi-valued logic and limited access orders, on the contrary, are more prone to social exchange processes - interactions.

Cultural and institutional differences can be regarded on the example of two neighboring nations - USA and Mexico: (i) in the absence of a greater power distance index value, American society, compared to the Mexican society, is less tolerant of inequality; (ii) having a lower uncertainty avoidance index, USA are more tolerant of uncertainty; (iii) USA are characterized by a higher individualism index value; (iv) USA have a lower masculinity (higher femininity) index value when compared to the Mexico, although the difference is not as great as with the aforementioned dimensions; (v) as to long-term vs. short-term orientation dimension, the USA are not a leader, however when compared to Mexico they are more long term oriented [7, p. 94].

Let us now compare two neighboring countries in Asia - China and India. The differences between the two are not only in culture, but also in terms of doing business and making foreign investments. In spite of many differences, there are some similarities between these two neighboring countries: (i) their economic success is based on implementation of large-scale process of reforms, which are constantly under review by the government; (ii) they use a five-year plan as a framework of economic policy and designing of reforms; (iii) both of them employ economic instruments, e.g. attraction of Foreign Direct Investment (FDI) through fiscal incentive, to increase country competitiveness; (iv) they created free trade zones to accommodate foreign investments: Special Economic Zones in China and Export Processing Zones in India; (v) the governments of both countries are willing to tackle the regional development problem and related issues to provide sustainable economic growth. Nowadays, China and India keep each other in their eyesight and view each other as competition. One of the current distinctions between China as the 'factory of the world' and India as the 'world's back office' in international trade may be changing in the coming decade, since China is aiming to develop its service sectors, whereas India hopes to move towards skill-neutral mass manufacturing [8, pp. 107-109].

On the corporate level, impact of culture on the example of Russian corporations is studied inter alia in [9] who underline some specific cultural characters of the organizations of inter-firm cooperation in the Russian industrial market and some of Russian-specific cultural factors applying to these organizations revealed by them. Here are these factors: (i) un- 
der the conditions of instability, personal relationships and past experiences of mutual obligations, which are factors in the formation of trust, are not able to fully mitigate the risks associated with specific assets. As a result, as asset specificity grows, while trust in the partner and confidence in the implementation of agreements is reduced; (ii) the weak legal institutions underpinning the Russian economy were found to exert a strong influence on the parameters of informal ties of the corporations' inter-firm cooperation; (iii) greater significance is accorded to the mechanisms impacting the partner and the control of the implementation of the contract, forming an alternative to trust; (iv) over the past decade, the consolidation of management functions began to implement control functions without, as a general rule, also unifying the assets of various actors, i.e. on the basis of legal independence [9, p. 50-51].

Another example of organizational or corporative culture, which matters for minimizing working capital being extremely important for any company that is willing to not only continue its existence, but more importantly, for a company willing to grow, is given in [10]. The conclusion is as follows: while many organizations might appear profitable on paper, quite often they find themselves in a position where they are unable to pay their shortterm debts as they come due, and, as a result, they are forced into bankruptcy. In order for companies to be efficient they need to strive towards minimizing their working capital, and if possible (depending on the industry and type of business) move towards negative working capital. However, there is a fine line between negative working capital resulting from highly efficient operations and negative working capital leading to bankruptcy. In a certain sense, working capital minimizing means the minimum that fits the company and increases its efficiencies.

On the regional level, the impact of culture and institutions is universal: it applies not only to developing and transitional countries, but also to fully industrialized and institutionally developed countries and the regions within these countries. For example, in one of the works on social capital in Italy Putnam et al. [11] show that the consequences of institutional changes in Italy in the 1970s are depicted, where the central government established 15 regional governments. It would seem that they all had to function more or less in a single key and come to similar results. In practice, everything turned out differently. And the reason was the deep differences between the central-northern and southern regions which date back centuries. Regions in which the institutions of free cities (free cities) - with the beginnings of participative democracy, political organization, providing their citizens with public goods, etc. were developed in the Middle Ages - were more advanced in the sense of civil and cooperative behavior of their citizens, whose culture was transmitted from generation to generation [12, p. 2].

Another example: in the USA there are least three coexisting subcultures - political culture-individualistic or individualistic (individualistic), moralistic (moralistic), and traditionalistic (traditional) [13] whose roots go into opposition to the «marketplace» (the pursuit by individuals of their own interests in the market and through the market) and the com- 
monwealth (the cooperation of individuals for achieving common goals rooted in moral principles)», with more or less pronounced regional localization [14, p. 4].

On the transitional level, the relevance of the cultural and institutional contexts are particular importance, because the strategy of reforms depends on the nature of the economic systems, assuming that the measure of the gradual and radical development processes is based on the internal systems of genotypic regularities, which include the conservative and liberal lifestyles, their change and unity. To effectively reform Russia, the Russian genotype mutations, characterized by the excessive dominance of conservatory order, need to be eliminated. This can be done through an evolutionary reform strategy, assuming both the transformation of the old order and the gradual construction of genotypic economic models. Institutional trajectory of modernization should start with the «top» level of the existing features of economic systems and be concluded with the consideration of the general genotypic regularities of the global economic system, which does not deny the cultural and socio-economic features of the countries and regions. See also a paper [15], where A. Arkhipov, B.Yerznkyan and E. Martishin analyze evolutionary-institutional patterns and factors of economic growth and development on the example of a number of countries, which have demonstrated the "economic miracle".

\section{CONCLUSION}

Recently, the topic concerning the importance of culture and institutions for economic outcomes and their influence on the economic process are taking on renewed relevance. Their relevance is of great importance at different levels and particularly in reforming the economy. Here are some conclusions of the paper.

National specificity is superimposed on genetics: on the whole, Western civilizations with their inherent two-valued logic of thinking and the dominance of open access orders in society are more prone to economic exchanges - transactions, while Eastern civilizations, with their multi-valued logic and limited access orders, on the contrary, are more prone to social exchange processes - interactions.

The restructuring of the world in American terms is ontologically meaningless and conceptually erroneous, because of universality of the requirement of an inordinate consideration of national characteristics - taking into account that even in the USA the coexistence of heterogeneous political subcultures is a reality that cannot be ignored.

The relevance of culture and institutions are of particular importance in reforming the economy. As demonstrated the Russian reforms, political factors, with uncritical transplantation of formal institutions, rather than economic factors played a significantly greater role in changing its trajectory of development. 


\section{REFERENCES}

1. North, D.C. (1990). Institutions, Institutional Change and Economic Performance. Cambridge: Cambridge University Press, 152.

2. Yerznkyan, B.H. (2016). The Influence of Culture on the Economic Behavior. Theory and Practice of Institutional Reforms in Russia: Collection of scientific works / Ed. by B.H. Yerznkyan. Issue 35. Moscow: CEMI RAS: 78-87.

3. Hofstede, G. (2011). Dimensionalizing Cultures: The Hofstede Model in Context. Online Readings in Psychology and Culture, 2(1).

4. Boyd, R., Richerson, P.J. (1985). Culture and the Evolutionary Process. Chicago: University of Chicago Press.

5. Yerznkyan, B. (2015). Evolution of Social Orders and Prospects of Economic Development // The Evolution of Economic Theory: Economic Reproduction, Technology, Institutions. St. Petersburg: Aletheia: 108-118 (in Russian).

6. Fukuyama, F. (1999). The Great Disruption: Human Nature and the Reconstitution of Social Order. New York: Free Press.

7. Adkisson, R.V. (2014). Quantifying Culture: Problems and Promises. Journal of Economic Issues, 48(1), 89-107.

8. Vardanyan, A. (2011). China and India: Major Differences of Doing Business. Theory and Practice of Institutional Reforms in Russia / Collection of scientific works ed. by B.H. Yerznkyan. Issue 20. Moscow: CEMI RAS, 105-109.

9. Popov, E., Simonova, V. (2015). The Impact of Culture on Inter-Firm Relations in Corporations. Montenegrin Journal of Economics, 11(1): 39-52.

10. Gassner, L. (2011). Minimizing Working Capital. Theory and Practice of Institutional Reforms in Russia / Collection of scientific works ed. by B.H. Yerznkyan. Issue 20. Moscow, CEMI RAS: 110-112.

11. Putnam, R., Leonardi, R., Nanetti, R.Y. (1993). Making Democracy Work. Princeton, NJ: Princeton University Press.

12. Alesina, A., Giuliano, P. (2013). Culture and Institutions. NBER Working Paper No. 19750. Cambridge, MA, 67.

13. Elazar, D.J. (1966). American Federalism: A View from the States. New York: Harper \& Row.

14. Wirt, F.M. (1991). "Soft" Concepts and "Hard" Data: A Research Review of Elazar's Political Culture. PUBLIUS: The Journal of Federalism, 21(2): 1-13.

15. Arkhipov, A.Y., Yerznkyan, B.H., Martishin, E.M. (2015). Anatomy of the "Economic Miracle". European Research Studies, 18(3): 7-20.

\section{Ерзнкян Б.А. \\ ЗНАЧЕНИЕ КУЛЬТУРНЫХ И ИНСТИТУЦИОНАЛЬНЫХ КОНТЕКСТОВ ДЛЯ УПРАВЛЕНИЯ КРУПНОМАСШТАБНЫМИ ЭКОСИСТЕМАМИ РАЗЛИЧНЫХ УРОВНЕЙ}

Анализируется значение культурных и институциональных контекстов для корректного понимания состояния и перспектив развития крупномасштабных экосистем раздичного уровня - национального, регионального, отраслевого, корпоративного и пр. Учет этих контекстов необходим для адекватного управления конкретными экосистемами. Ключевые слова: институциональный контескт, культурный контекст, крупномасштабные экосистемы, управление.

JEL классификащия: А12, B40, D21, M12, M14, O15, P00, Z10. 